\title{
The Role of Industrial Incentives in Development of Small and Medium Industries
}

\author{
Afshin Rahnama (Corresponding author) \\ Faculty of Management and Accounting, Islamic Azad University \\ Qazvin Branch, Qazvin, Iran \\ E-mail:Afshin.Rahnama@yahoo.com \\ Seyyed Javad Mousavian \\ Department of Management, Astara Branch \\ Islamic Azad University, Astara, Iran \\ E-mail:saba_moosaviyan@yahoo.com \\ Dariush Eshghi \\ Department of Business management \\ Islamic Azad University, Naragh Branch, Iran \\ Abbas Alaei \\ Graduate of Executive Management \\ Financial Export of Mellat Bank, Pars Abad Branch, Iran
}

Received: September 2, 2011

Accepted: October 25, $2011 \quad$ Published: November 21, 2011

doi:10.5430/ijba.v2n4p25

URL: http://dx.doi.org/10.5430/ ijba.v2n4p25

\begin{abstract}
Small and medium industries have had a significant impact on creation of new employment opportunities in recent years. In other words, in today's modern world, small and medium industries have a significant role in variables like economic growth, competitiveness, and resolution of the ubiquitous unemployment crisis. Even though large-scale industries are still important in economic policy-making due to their economy of scale, the effect of massive production, experience, and organization, small and medium industries have some advantages including transportation, market size, regulations, choice effectiveness, and control. Accordingly, these industries have become the first choice for the production of most goods.

This study investigated the role of industrial incentives in the development of small and medium industries in East Azerbaijan province. Based on the review of articles, texts, relevant sources, and comments from experts, relevant indicators were defined for each component of industrial incentives. Based on these indicators, a questionnaire was developed with 30 questions. After testing the validity and reliability of the questionnaire, it was applied to statistical samples using stratified random sampling. Then the questionnaires were collected and the obtained information was analyzed using descriptive statistics as well as inferential statistics (Spearman correlation test $r$ and step by step Regression). The results show that there is a statistically significant relationship between the variables in this study. and obtained Results of regression Analysis shows that across 4 indicators Industrial Incentives, 2 indicators of it, that is, Financial and Customal Incentives were appropriate predicators for Development of Small and Medium Industries.
\end{abstract}

Keywords: Industrial Incentives, Small Industries, Medium Industries 


\section{Introduction}

Small and medium sized companies play an important role in creating new jobs, novelty, flexibility and economic growth (Birch, 1979). There are plenty of evidences showing that new small companies grow faster (Evans, 1987; Wager, 1994; Cabral, 1995; Tether et al., 1998; Braxy et al., 1999) produce more transparent jobs, distribute wealth more efficiently (Schumpeter, 1942) and bring about more novelty (Chakrabarti, 1991). Economists attribute new companies failure to production process inefficiency and their organizational design. New companies establishment and their entrance to an industry, as a whole, is a key element in economical growth and industry development (Schumpeter, 1934). New companies are more susceptible to withdrawal risk (especially in the early years of entrance) (Geroski, 1995). Established companies are at the risk of quake in industry due to technology varying nature (Gort, \&Klepper, 1982). Examining small and medium sized companies and effective factors is of great importance since small and medium sized companies can decrease unemployment, they act as a balance function in market and in the long term, cause profitability and price levels reach a competitive level (Audretsch et al., 1999). These new companies entrance in long term, removes excessive profits (Mueller, 1990). And also productive economies through creating small and medium companies, during time, orient their specializing process towards products with more powerful competitive abilities (Holmes et al., 1999). Also, today in most of the world countries small and medium industries in various aspects such as social, industrial production and service delivery are creating roles. In most of these countries, these industries are main providers of new occupation, origin of evolution and novelty and pioneer in inventing new technologies. These industries with their significant exports play an effective role in countries economical developments.

Although some of developed countries like United States, due to dominance of formalism attitudes over their country industrial development policies up to 1980s, neglected small industries, since some decades ago, many other countries which small and medium industries play a significant role in their industrial structure has established some policies in supporting and developing this part of industry.

Small industries due to various reasons such as providing people primary demands, more employment, being in production transfer stage, economical justice development and ....... are of great significance and play an important role in society's economy. So that in some of the world countries, small industries are considered as social and economical development axis. Its apparent examples are Asia eastern south countries like Sothern Korea, japan and Singapore.

Small and medium industries with all their virtues (such as: appropriate foundation for increasing the level of social stability, creating productive occupations and training and preparing human forces of large industrial units, enjoying extensive talent to provide some of the large production units needed industrial segments and imperfect goods with less price than large units), due to activity in limited level and having few resources, financial and human possibilities, confront with lots of difficulties in various fields of financial management, marketing, and sale. In dividing the industry in to small, medium and large, according to staff number and investment volume or any other basis, what seems to be considered is enterprises size and their strength to tolerate economical various conditions. There is no doubt that large industries, particularly state industries, due to accessibility to more extensive and cheaper financial and informational resources, are more efficient in controlling problems and issues and their existence is threatened less but small industries particularly industries related to private section are engaged with more issues and problems and should be supported, especially if small industries in some of regions play the main and major role in economy.

In our country, in spite of significant presence of small industries in its industrial structure, due to same attitude towards policies of production units, small and medium industries face various troubles so that they are unable to fulfill their expected commitment like developed and developing countries.

\section{Research Theoretical Background}

\subsection{Small and Medium Industries}

With respect to small and medium enterprises definition in Iran there is little consensus. Different ministries, institutions and organizations have offered various definitions.in various organizations definition, employees number index is considered in joint, for instance, according to central bank fewer than ten staff industries are considered small and more than 10 staff industries are considered large industries. Mines and industry ministry as a main proctor of country industries consider six up to twenty staff industries as small and more that twenty nine up to one hundred and fifty staff ones as medium industries(Nasrin Doost, 2009).

According to another definition, small and medium enterprises are production-commercial units, which are placed in lower hierarchy in comparison with large companies, in categorizing companies in terms of size. 
Usually these enterprises classification is dependent on four main indexes:

1-enterprise employees' number

2-enterprise total net assets

3-the amount of enterprise sales level

4- the amount of enterprise investment.

Employee number is the most important and common index to define small and medium enterprises size. Although this index is different in various countries in terms of number, most countries define small and medium enterprises in definite spectrum of one to two hundred and fifty employees (Zadehvakili, 2007).

Industrial incentives: industrial incentives are collections of supports, researches and exemptions which are organized and executed in the forms of regulations, on the part of government to support industry (Mardanigivi, 2004).

Financial incentives: government direct and indirect attribution to industry that is specialized to establish or develop a business and is expected to pave the way for job creation (Noroozzadeh, 2008).

Tax incentives: is the extent of exemption and tax discounts that includes small industries due to special activity in a case, or due to being in a region (Khodabakhshi, 2007).

Customs incentives: it is a kind of support due to which small industries in their goods import are exempted from paying salary or customs duties or discounts are applied to them(Noroozzadeh, 2008)..

Export incentives: is the amount of attributions and supports which is granted on the part of government to help exporters of goods or private section services with small production clusters in the form of purchaser, seller and circulated capital credit. (Carig, Jackson\&Thomson, 2007).

\subsection{The Role of Small and Medium Industries}

One of the industrial development ways that has recently been considered by developing or even developed countries is relying upon downsizing industry and dependence upon small and medium industries expansion and development as an industrial and economical development motor. According to international societies and world various institutes such as global bank and international monetary fund small and medium enterprises play a determinant role in creating jobs, society's economy progress and prosperity; so that developed and developing countries especially in east and eastern south of Asia ,with employing cohesive and comprehensive policies in this field have taken significant measures in reducing economical and social crisis, unemployment being the most prevalent of which . Considering the importance of small and medium companies it is required that some studies be carried out to distinguish these enterprises barriers, difficulties and needs and in this way help them so that they find a suitable position in international and competitive arenas (Zadehvakili, 2007).

Regulations related to industrial incentives (tax, financial, customs, employment, export, training, ground appropriation, installments exemption and allowance to make use of establishments) in Iran small industries, in spite of enjoying significant privileges and virtues in country industrial and economical development, have been in various straits that led to these industries cessation (Farzanevash, 2005).

A brief glance at the various countries economical system structure makes us more familiar with status and importance of companies and small and medium enterprises. With respect to these companies importance, suffice to say that at least there are 3/2 million small and medium enterprises in Germany with the staff number of twenty million that encompass 70 percent of this country whole employees. In United States there are almost 25 million small enterprises that possess more than 50 percent of private section work force. These enterprises alone provide half of the United States home gross production and 96 percent of this country whole export is produced by these companies.

These companies due to their particular characteristics enjoy unique functions:

Small enterprises enjoy more flexibility and novelty, creativity and job creation occur more in them.

Small enterprises are the enterprise of a wide section of countries population employment and recruitment and skillful work force instruction and training.

For large companies, specialized work force preparation is usually carried out through small and medium enterprises.

Since small enterprises compared to medium enterprises and large industries can produce job with less capital, the number of jobs produced by these sorts of companies is more than ones produced by large companies.

The possibility of producing jobs in the self employment manner makes job producers fall back on these kinds of companies with more motivation.

Recruitment and acceptation of employees with special conditions is carried out more easily in these enterprises. 


\subsection{Small and Medium Industries Special Attributes}

Small and medium industries are so extensive and their attributes are so desirable that they can play a determinant role in industrial growth and development and social justice on one hand and human elevation and cultural promotion in different societies on the other hand. Part of these attributes is as following:

Small and medium industries have the most capability to produce productive and instructive occupations particularly to guide wide groups of young people and country active forces.

Small and medium industries have necessary technical and special capabilities to produce and provide most of home and foreign large industries needed segments and imperfect goods.

Small and medium industries with their producing large industries needed segments and imperfect goods give this opportunity and possibility to large industries programmers to manage producing various goods simultaneously. In addition to changing factory production line and producing goods with more advanced technologies, by selling industrial equipment and segments, they maintain home consumption markets for factories for long time.

Small and medium industries made the most contributions in removing privation and producing productive occupations in countries deprived and less developed regions.

Small and medium industries are the best foundation to train large industries required managers and specialist human forces with more advanced industrial technologies in all of the countries.

\subsection{Small and Medium Industries Problem in Iran}

Lack of necessary possibilities to promote employment or job production and some attempts to create required basis for it.

Problems related to country financial regulations and other bureaucratic requirements.

Lack of possibility to create networks for interrelationship between enterprises and universities and research institutes.

Lack of attention to informational and commucational technology development issues.

Supplying production required basic materials (Molaei,2005).

\subsection{Research Hypotheses}

According to carried out studies and examination of topic related literature and research main target, this research assumptions are organized as the following:

There is a significant relationship between eastern Azerbaijan province small and medium industries industrial and developmental incentives.

1-1-there is a significant relationship between eastern Azerbaijan province small and medium industries financial and developmental incentives.

1-2- there is a significant relationship between eastern Azerbaijan province small and medium industries fax and developmental incentives.

1-3-there is a significant relationship between eastern Azerbaijan province small and medium industries customs and developmental incentives.

1-4-there is a significant relationship between eastern Azerbaijan province small and medium industries export and developmental incentives.

\section{Research Methodology}

According to target, this study is practical and according to method it is descriptive-survey and since surveyor takes part in companies environment and gather this study data using questionnaire, this study is categorized as field study.

\subsection{Research Place Territory}

This study has been carried out in the entire small and medium industries dependent upon eastern Azerbaijan province industry and mines organization.

\subsection{Research Time Territory}

Regarding this fact that the study has been carried out in the time intervals between April, 1389 and October, 1389, in this time interval 2756 active small and medium industrial units have been identified in the province industrial complexes. 


\subsection{Sampling Method and Sample Volume Determination}

Taking this into considerations that statistical society enjoys almost identical characteristics, so statistical society is considered homogeneous. Required sample number, based on Morgan table has been obtained equal to 338 with assurance level of $95 \%$. To choose statistical sample classical sampling method has been used in which small and medium industries settled in eastern Azerbaijan province and in proportion to people number of 36 classes, questionnaires were distributed between them.

\subsection{Information Gathering Device}

Data gathering device in present study is questionnaire through library studies.

Applied questionnaire totally contains 30 questions, for each of these components, financial exemptions, tax exemptions, customs exemptions, export exemptions, 5 questions, and for industries growth component, 10 questions is allocated.

For each of them question collection was measured through Likert spectrum criteria.

To examine questionnaires reliability, questionnaires were applied upon 30 people of statistical society and using Kronbakh alphabet, acquired value for industrial incentives was $0 / 87$ and for industries growth component it was $0 / 71$ that below industrial incentives components, respectively with alpha coefficients of $0 / 71,0 / 74,0 / 64,0 / 69$, indicates high validity for designed questionnaires.

\section{Data Analysis}

For analyzing data, first to examine whether grades distribution is normal or not, Kolmogorov-Smirnoff test and to examine relations between variables, correlation test, and eventually to predict industries growth through industrial incentives components, step by step regression were used.

\subsection{Kolmogorov-Smirnoff (K-S) Test to Determine Grades Distribution Normality}

In current study to examine small and medium industries growth grade distribution, industrial incentives and its components (financial incentives, tax incentives, customs incentives and export incentives) Kolmogorov Simonov statistical test has been used to examine data normality as a premise to use required typical test. In table 1 obtained results are showed.

\subsection{Test Assumptions Determination}

HO: observations distribution is normal.

HI: observations distribution isn't normal.

$<$ Table 1 about here $>$

As it is shown in above table, significance value related to this test in all of the variables is considered less than significance value $(0 / 5)$. So hypothesis zero is rejected and variables distribution is abnormal therefore to examine relations between variables nonparametric spearman test is used.

\section{Testing Hypothesis}

Considering data distribution abnormality, we use spearman correlation coefficient. Spearman correlation test makes it possible to examine its significance with including significance level $(\alpha=0 / 5)$. Since statistical software Spss has been used in this study and considering that calculating spearman correlation coefficient, the software obtain its significance level; so in analysis results whenever significance level is below $0 / 5$, this conclusion has been made that there is a relationship between dimensions. If significance level is higher than $0 / 5$, lack of any relationship between considered variables is shown. Table 2 shows spearman correlation coefficient along with their significance level.

$<$ Table 2 about here $>$

According to Spss output, and since correlation coefficient for all of coefficients is considered less than significant value $(0 / 5)$, so existence of a relationship between study variables can not be denied and hence it can be said that there is a significant relationship between study variables. Also, all of the correlation coefficients for the entire relations is positive and being positive is an indicative of criteria variable (dependent) increase with predictive variable (independent) increase.

According to computed coefficients based on table 2 development industrial incentives along with development customs incentives with correlation coefficient of $0 / 49$ have the most relationship with small and medium industries development variable and tax incentives with correlation coefficient of $0 / 23$ have the least relationship with small and medium industries development variable. 


\subsection{Step By Step Regression}

In Pearson correlation method, relation between dependent variable and studied independent variables, assuming most of the other variables as stable, is examined separately, but practically, these factors act upon dependent variable simultaneously and at once and surveyor should examine them simultaneously. Examining independent variable simultaneous impact upon dependent variable, various results are likely to be obtained. To predict these factors simultaneous impact multiple regressions has been used. To predict eastern Azerbaijan small and medium industries development through industrial incentive components, multiple regression with step by step method has been used. In this method available predictive variables entrance is not feasible and this action is carried out through correlation coefficient, if variable obtains entrance criteria it remains in analysis otherwise it is omitted.

At least, industrial incentive two components including customs and financial incentives obtained entrance criteria and tax and export incentives were removed from regression.

\section{$<$ Table 3 about here $>$}

Obtained results from table3 step by step regression analysis showed that two components of customs and financial incentives as predictive variables of regression final equation entrance criteria possess criteria variable for small and medium industries development. From table7 it can bee seen that the intensity of relation between customs incentives for the province small and medium industries development is $0 / 486$, and with financial incentives entrance this amount has climbed up to 0/556. Coefficient of determination column indicates that in table 7, 31 percent of variations in the province small and medium industries are predictable through two components of industrial incentives. Also, variance analysis in table 8 shows that the regression is significant and confirms the existence of linear relationship between variables.

\section{$<$ Table 4 about here $>$}

$<$ Table 5 about here $>$

Table number3 shows regression coefficients and $\mathrm{T}$ test for examining these coefficients and significant level of them. Beta column shows that with variation of one standard deviation in component of customs incentive, there occurs $0 / 49$ standard deviation in eastern Azerbaijan province small and medium industries development. In this way, for one standard deviation variation in financial incentive, 0/29 standard deviation in the province small and medium industries development occurs. On this basis, customs incentive compared to financial incentive has the most impact upon eastern Azerbaijan province small and medium industries development.

\section{Conclusion and Suggestions}

According to obtained correlation coefficient, predictive variable "industrial incentives" has relation value of $0 / 49$ with eastern Azerbaijan province small and medium industries development meaning that with industrial incentives increase, the extent of eastern Azerbaijan province small and medium industries development will increase too since there is obtained a positive and significant relationship between predictive variable and criteria. But in relation to the study presuppositions that includes various incentives, the study result indicates positive and significant relationships between financial , tax, export and customs incentives, among these, according to multiple regression computation with step by step method, customs and financial incentives compared to other incentives has the most prediction in statistical respect upon the province small and medium industries development and customs incentive with standard deviation of 0/49 has the most impact. In spearman correlation coefficient what was observable was that customs and financial incentives have the most significance relationship between four factors and export and tax incentives has the least relationship with eastern province small and medium industries development, but in ranking variables it should be said that customs incentives besides having the highest significance relationship posses the highest predictive grade and are placed after financial incentives. So according to obtained results it is suggested that:

1-financial and customs incentives improvement: in this study it is made known that customs and financial incentives have the most significant relation with eastern Azerbaijan province small and medium industries development. So it is suggested that to improve these incentives government grant necessary and efficient financial resources to eastern Azerbaijan small and medium industries with lower interest rate and also by creating necessary foundation assist industries in machinery and basic materials import .

2-tax incentives improvement: this study results show that tax incentives have positive relation with eastern Azerbaijan province small and medium industries development. On this basis it is suggested that government in the long term assist more by legislating flexible tax regulations in with attention to activity kind and small and medium industries size and also by offering tax discounts. 
3-export incentives improvement: in this study it is made known that export incentives have positive relation with eastern Azerbaijan province small and medium industries development. So it is suggested that government with attention to export incentives indexes, take necessary measures in complete enforcing of these incentives in industry, for entrance in to global and regional markets.

\section{References}

Audretsch, D.B., Santarelli, E., and Vivarelli, M. (1999). Start-up size and industrial dynamics: some evidence from Italian manufacturing. International Journal of Industrial Organization Vol. 17, pp.83- 965. http://dx.doi.org/10.1016/S0167-7187(98)00002-2

Birch, D. (1979). The job generation process. Combride, MA: M.I.T. Program on neighborhood and regional change.

Brixy, U., and Susanne, K. (1999). Employment growth determinants in new firms in eastern Germany, Small Business Economics 13, p. 155-170. http://dx.doi.org/10.1023/A:1008177312335

Cabral, L. (1995). Cost, Firm size and Firm growth. Journal of Industrial Economics 43(2), p. 161-172. http://dx.doi.org/10.2307/2950479

Chakrabarti, A. K. (1991). Industry characteristics influencing the technical output, A case of small and medium- sized firms in the use. $R \& D$ Management 21(2), p. 139- 152. http://dx.doi.org/10.1111/j.1467-9310.1991.tb00743.x

Craig, B. R., Jackson III, W. E., and Thomson, J. B. (2007). Small Firm Finance, Credit Rationing, and the, Impact of SBA, Guaranteed Lending on Local, Industry and Economic Growth, Journal of Small Business Management 45(1), pp. 116-132. http://dx.doi.org/10.1111/j.1540-627X.2007.00202.x

Evans, D. S. (1987).The relationship between firm growth, size and age: estimates for 100 manufacturing industries. The Journal of Industrial Economics 35(4), pp. 567- 581. http://dx.doi.org/10.2307/2098588

Farzanevash, B. (2005). City and Industry. Public Relations Publications Industrial Ardabil Province,first publish.

Geroski, P. A. (1995).What do we know about entry? International Journal of Industrial Organization 13(4), pp. 421440. http://dx.doi.org/10.1016/0167-7187(95)00498-X

Gort, M., and Klepper, S. (1982). Time paths in the diffusion of product innovations, The Economic Journal 92(367), pp. 630- 653. http://dx.doi.org/10.2307/2232554

Hosayni, M., Ahmadinezhad, M., and Ghaderi, S. (2010). Evaluation and measurement of service quality and its relationship with customer satisfaction (case study: Tejarat Bank). Journal of Commerce,Vol42.

Khaki, G.. (2009). Research in Management. Baztab Publication.

Khodabakhshi hafshjani, N. (2007). Public Accounting. Negin publication,Ardabil.

Mardani givi, E. (2004). Small industry in Iran. Tadbir, Vol.137.

Molaei, M. (2005). Modernizationsmall industry in Iran. Tadbir, Vol.150.

Mueller, D.C. (Ed.). (1990). The Dynamics of Company Profits: An International Comparison. Cambridge University Press, Cambridge.

Nasrindoust, T. (2009). The situation in Iran and some small and medium enterprises from different countries. Office of industry and mines, Tehran.

Norouzzadeh, A. (2008). The effect of Funds received and tax on the growth of small industries in Ardabil. MS Thesis, Tabriz Islamic Azad University.

Schumpeter, J. (1934). The Theory of Economic Development, Cambridge: Harvard University Press.

Schumpeter, J. (1942). Capitalism, Socialism and Democracy, NewYork: Harper and Row.

Tether, B.S., and Massini, S. (1998). Employment creation in small technological and design innovators in the U.K. during the 1980s, Small Business Economics 11, p. 353- 370. http://dx.doi.org/10.1023/A:1008065115819

Zadehvakili, K. (2007). Small and medium enterprises. Development and trade organization web. 
Table 1. Kolmogorov-Smirnoff Test

\begin{tabular}{|c|c|c|c|c|c|c|c|}
\hline \multirow{2}{*}{$N$} & Growth & Financial & Tax & Customs & Export & Industrial \\
\cline { 3 - 8 } & 338 & 338 & 338 & 338 & 338 & 338 \\
\hline \multirow{2}{*}{ Normal parameters } & Average & 28.9231 & 14.2722 & 13.4201 & 12.7012 & 14.1243 & 54.4763 \\
\cline { 2 - 8 } & Standard deviation & 9.82457 & 3.23966 & 3.35105 & 3.51124 & 2.97107 & 8.43483 \\
\hline \multicolumn{2}{|c|}{ Kolmogorov-Smirnoff } & 2.101 & 1.975 & 3.888 & 2.521 & 2.981 & 1.523 \\
\hline \multicolumn{2}{|c|}{ Significant value } & .000 & .000 & .000 & .000 & .000 & .000 \\
\hline
\end{tabular}

Table 2. Correlation Test Table

\begin{tabular}{|c|c|c|c|}
\hline Variables name & Coefficient correlation & Significance value & significant relation \\
\hline Development industrial incentives & 0.4 & 0.000 & There is \\
\hline Development financial incentives & 0.43 & 0.000 & There is \\
\hline Development tax incentives & 0.23 & 0.000 & There is \\
\hline Development customs incentives & 0.49 & 0.000 & There is \\
\hline Export incentives development & 0.33 & 0.000 & There is \\
\hline
\end{tabular}

Table 3. Step by Step Regression Results

\begin{tabular}{|c|c|c|}
\hline Model & Multiple correlation coefficient R & Coefficient of determination R2 \\
\hline 1 & 0.486 & 0.236 \\
\hline 2 & 0.556 & 0.309 \\
\hline
\end{tabular}

Table 4. Variance Determination for Table3

\begin{tabular}{|c|c|c|}
\hline Model & $\mathrm{F}$ & significant level \\
\hline 1 & $103 / 796$ & 0.000 \\
\hline 2 & $74 / 934$ & 0.000 \\
\hline
\end{tabular}

Table 5. Regression Analysis Results

\begin{tabular}{|c|c|c|c|c|}
\hline Parameter & B & Beta & T & Significant level \\
\hline Stable coefficient & $19 / 813$ & & $24 / 211$ & $0 / 000$ \\
\hline Customs incentive & $0 / 555$ & $0 / 486$ & $10 / 188$ & $0 / 000$ \\
\hline Financial incentive & $0 / 267$ & $0 / 289$ & $5 / 953$ & $0 / 000$ \\
\hline
\end{tabular}

